\title{
The Struggle to Survive: The Power of Partnerships in the Quest for Nonprofit Sustainability
}

\author{
Karl Besel \\ Ngoan Hoang \\ Richard Cloud \\ Seana Golder \\ Linda Bledsoe \\ Patrick McKiernan
}

\begin{abstract}
This article provides information about a Youth Service Bureau's (YSB) experiencein collaborating with court officials to expand services and a subsequent funding base. YSBs, likemany other nonprofit human service agencies, have found that partnering with local governmental officials, especially judges, can enhance sustainability. Implications for strengthening partnerships between local nonprofits and countyjudges are discussed.
\end{abstract}

Keywords: Family courts, governmental funds, funding nonprofit organizations

$\mathrm{O}$ btaining and maintaining funding over an extended period is a critical issue in the survival of nonprofit agencies. However, systematic research about the survival of nonprofits was almost nonexistent until the 1990s. Most studies conducted on organizational behavior have focused on productivity or profitability, rather than survival (Peters \& Waterman, 1982). Furthermore, the limited number of studies on organizational survival have typically used for-profit or public organizations for analysis (Sheppard, 1995). In light of the substantial role nonprofits such as Youth Service Bureaus (YSBs) play in addressing human service issues through a variety of court-related services, the ability of communities to provide quality programs is intricately linked to nonprofit sustainability and survival.

This article examined the process of creatingand maintaining partnerships between local nonprofits and court officials to expand services and funding for addressing human service issues. In particular, the authors examined and provided information on how a YSB was able to obtain funding over an extended period of time.

Karl Besel is assistant professor, Kent School of Social Work, University of Louisville, Louisville, KY, 40292. Ngoan Hoang is assistant professor, School of Nursing, Indiana University, Columbus, IN 47203. Richard Cloud, Seana Golder, and Linda Bledsoe are assistant professors at Kent School of Social Work, University of Louisville, Louisville, KY, 40292. Patrick McKiernan works for Volunteers of America, Louisville, KY, 40203.

Copyright $^{\oplus} 2004$ Advances in Social Work Vol. 5 No. 2 (Fall 2004) 139-149.

Indiana University School of Social Work. 


\section{LITERATURE REVEW}

Throughout the 1990s, nonprofit agencies created or expanded services to implement many court-directed strategies. Possibly the most innovative local court creations were implemented by community-based nonprofit agencies. These innovations included the development and expansion of divorce education classes (Blaisure \& Geasler, 1996), supervised visitation and exchange programs (Clement, 1998), and a host of juvenile justice programs (Kaye \& Lippman, 1998). Until recently, however, little attention was given to how these typically small and budget strapped nonprofits acquire sustainable resources. While the number of studies on nonprofit survival has generally increased (i.e., Galaskiewicz \& Bielefeld, 1998; Gronberg, 1993), relatively little is known about how court officials can work to enhance the survival of their greatest ally—the local nonprofit agencies.

\section{The Relationship Between Agency Survival and Recent Policy Initiatives}

Organizational survival has become increasingly important for nonprofit agencies over the past decade (Bocage, Homonoff \& Riley, 1995: Jarman-Rohde, McFall, Kolar \& Strom, 1997). Due to federal and state funding cuts that began during the Reagan Era, nonprofit organizations continue to explore innovative ways to sustain their operations (Motenko, et al., 1995). Typically, these strategies employ merging, decentralizing, or cost-cutting measures that parallel recent trends in the for-profit sector (Ortiz \& Bassof, 1988; Strom-Gottfried, 1997).

Consistent with reductions in fiscal support for human services that took root in the mid-1980s, and political and policy changes that continued into the next decade, the 1990s witnessed a push toward nonprofits providing welfare-to-work programs. Federal granting institutions earmarked considerable funding for nonprofits to develop training, mentoring, and cultural sensitivity programs on behalf of welfare recipients (Family Services Report, 1999). In addition, nonprofit organizations were also being encouraged to expand their existing programming to address childcare, counseling, transportation, and housing needs so that welfare recipients would have the necessary resources to continue employment once they were adequately trained.

A multitude of federal grant opportunities have been available to nonprofit organizations that provide educational, job training, and other human services to low-income families since Welfare-to-Work legislation was passed (Family Services Report, 1999). At first glance, governmental strategies that provide significant monetary incentives for nonprofits to pursue welfare-to-work related programs give the appearance of systematic planning to promote sustainability and survival among nonprofit agencies. However, these legislative efforts do not adequately account for or address the previous difficulties in sustaining locally based nonprofits. For example, the Community Mental Health Centers Act of 1963 resulted in the creation of community-based mental health organizations that could be accessed by every American citizen regardless of income. Similar to welfare-towork strategies, federal funds were granted to community-based mental health organizations, with the eventual goal of sustainability by local and/ or state funding. Yet, many of these mental health agencies were forced to close operation (Greer \& Greer, 1983). Ultimately, many of the surviving organizations had to 
develop private sector growth strategies that made their services less accessible to low-income clients (Greer \& Greer, 1983). Despite increased reliance on private sector practices such as collecting fees for services and third-party reimbursements, nonprofits continue to rely heavily on governmental sources for survival.

Nonprofits' increased reliance on public funds over the past 50 years has been termed "voluntary failure" (Salamon, 1987). According to Salamon (1987), American communities have traditionally relied on nonprofits to provide human services as a result of "market failure," or the inability of the private sector to deliver human services at a profit, especially within less affluent communities. As populations of American cities skyrocketed in the late 1800s, nonprofits that traditionally relied upon charitable giving for survival became increasingly dependent upon governmental grants and contracts to sustain their operations. Thus, voluntary failure was evident by the end of the $20^{\text {th }}$ century as a result of the symbiotic relationship that had developed between governmental funders and these agencies. For example, the three largest religiously affiliated social service agencies in the U.S., Catholic Charities, Lutheran Social Services, and the Salvation Army, all receive more than half of their annual program revenues from governmental sources (Shafritz \& Russell, 2003). The Bush Administration's Faith Based and Community Initiative that was passed this year seems to demonstrate that many federal officials (and their constituents) are in favor of perpetuating this trend of reliance on government funds by religiously affiliated nonprofits. In light of the history of past public policy initiatives such as the Community Mental Health Act, this recent initiative may do little to foster the long-term sustainability of these faith-based organizations.

\section{Role of Local Governments in Nonprofit Survival}

Although county governments have historically played a direct role in service delivery to incorporated urban areas, few studies have explored this area. Since the 1970s, counties have had a more significant role in funding social services than city governments (Peterson \& Strachota, 1991). Most cities invest only small amounts in social welfare functions. In contrast, county governments spend upwards of $17 \%$ of their total budgets on current operating expenses for social services (Scheider \& Park, 1989).

The expanded role of counties as providers of human services has been coupled with cutbacks in state and federal funds to support local communities. By the 1980s, federal support of local communities consisted primarily of funds for developmental services such as construction of interstate road networks (Petersen \& Stracota, 1991). County governments that were al ready fiscally strapped became significant funding sources for local nonprofit organizations such as youth service bureaus. The growth and expansion of locally based United Way organizations and community foundations coincide with this reliance on county entities to fund human services.

\section{Court-Related Nonprofits: A Brief History of Youth Service Bureaus}

Youth Service Bureaus are a key example of community-based agencies that have consistently served family courts through a variety of human service programs. In most cases, these organizations have operated as nonprofit agencies at the city or 
county level. Youth service bureaus were initiated throughout the U.S. following a funding recommendation by the President's Commission on Law Enforcement and Administration of Justice in the 1960s (IYSA Red Book, 2002).

Indiana's experience and the establishment of youth services bureaus provides an illustrative example of the process of creating and maintaining partnerships between local nonprofits and court officials to expand services and funding for addressing human service issues. In Indiana, many counties were able to establish youth service bureaus as a result of federal "start-up" grants. Federal officials provided funds to county-based youth service bureaus with the understanding that communities would eventually sustain these bureaus through local governmental bodies, United Ways, and other county-based funding institutions. County judges often initiated funding requests to governmental institutions to initiate bureaus and, in cases such as the Monroe County bureau, served as the agency(s) first presidents. Subsequently, bureaus such as theones started in LaPorteand Porter counties had county judges working in tandem with the Women League of Voters in submitting initial funding requests to the federal government (Besel, 2000). At their peak as many as 45 bureaus operated in Indiana. When federal funding dried up in the middle 1970s, many of the bureaus were unable to generate enough local funds to continue services and were therefore forced to close operation. Many of the bureaus that survived the depletion of federal funds were able to exhibit significant growth during the late 1980s and early 1990s. Furthermore, thenumber of bureaus operating statewide expanded significantly throughout the 1990s (Besel, 2001).

The growth patterns and funding dilemmas of the Indiana youth service bureaus have run in tandem with national growth trends in the nonprofit sector. While the nonprofit sector as a whole experienced significant growth during the 1980s by increasing its share of total earnings from $6.4 \%$ ( $\$ 75.9$ billion) to $7.8 \%$ ( $\$ 254.8$ billion), as well as experiencing percentage increases in government payments from 1987 to 1992, human service organizations took the bulk of cutbacks in federal funding that occurred during the 1980s. Between 1977 and 1989, the social and legal services subsector share of total annual funds as a percentage of total funds for the nonprofit sector declined from $10.2 \%$ in 1977 to a low of $8.9 \%$ in 1987, then increased its share to $9.5 \%$ in 1989 . Over this period, government support as a proportion of this subsector's total annual funds steadily declined from $54.3 \%$ to $41.4 \%$ in 1987, then increased slightly to $42.0 \%$ in 1990 (Hodgkinson, Weitzman, Toppe \& Noga, 1992). In 1992, this subsector witnessed an increase of $50 \%$ with regard to governmental payments (Hodgkinson, Weitzman, Abrahams, Crutchfield \& Stevenson, 1996). It is significant to note that this potential reversal in the percentage of funding received by human service nonprofits during the early 1990s still did not bring the social and legal services subsector up to the 1987 government funding level.

\section{SETTING}

Johnson County, Indiana, celebrated its $175^{\text {th }}$ anniversary in 1998. Johnson County was settled early in the nineteenth century and the area soon grew to become an important agricultural and manufacturing center. As a result of the county's close 
proximity to Indianapolis, the growth of the metropolitan area has had a lasting impact on Johnson County, especially during the 1960s and 1970s. The rapid growth of Indianapolis during this time period induced the construction of suburban tract housing in many areas around Greenwood in northern Johnson County. Within a 10-year time period during the middle 1970s and 1980s, the population of the Greenwood almost doubled (Division of Historic Preservation \& Archaeology, 1985).

The significant growth experienced by Johnson County during this time was coupled with an increased demand for community-based efforts to prevent juvenile delinquency. The establishment of a county-based youth service bureau was viewed by community leaders and local citizens as an effective means of addressing status offenses and providing temporary shelter for youth who were often victims of abuse and neglect.

\section{THE FUNDING EXPERIENCE}

Efforts to begin a youth service bureau in Johnson County began in the midst of this period of rapid bureau expansion throughout Indiana. In June of 1976, a group of concerned citizens discussed the need for a shelter care facility that would serve as an alternative to placing juveniles in the county jail. The enthusiasm of this initial group sparked the mobilization of citizens throughout the county. With the assistance of the Indiana Juvenile Justice Task Force, the Johnson County Chapter of the Juvenile Justice Task Force was initiated in July of 1976. This communitybased volunteer network began to formulate strategies for the provision of court diversion and shelter care services.

By October 1976, the Johnson County Youth Service Bureau (JCYSB) was incorporated and a nine-member board of directors was elected. Initial funding for bureau operations was provided through the federal Comprehensive Employment and Training Act (CETA) funds, the Indiana Department of Public Instruction, and a federal grant from the Law Enforcement Assistance Administration. When substantial federal grants available to Indiana youth service bureaus dried up during the late 1970s, JCYSB became more reliant on state and local sources for program funding. While the Bureau experienced significant shifts in service delivery strategies, including the closing of its shelter care facility in 1995, it has continued to rely on county-based funds for program sustainability. The process of acquiring funding from local institutions during the 1980s and 1990s often involved local judges (JCYSB Historical Report, 1996). Subsequently, these county judges often met with members of the Board of Commissioners the week prior to their budget hearings at the request of JCYSB board members (JCYSB Board Minutes, 1997, 1998). These "behind the scenes" meetings between county judges and Board of Commissioners members set the stage for the YSB being able to consistently secure program funding.

\section{Bureau Dependency on County Funding}

Table 1 demonstrates how dependent JCYSB was on county governmental funding during the early 1990s. Most of the county funding provided to the bureau throughout its history came in the form of per diem payments provided for the 
agency's Youth Home. When the Youth Home closed in October 1994, the bureau witnessed a tremendous cut in annual revenue. While the small nonprofit agency was forced to implement new programming strategies as a result of its primary service closing, bureau staff and board members exhibited considerable success in acquiring new funding from their county government. This section provides a summary of three incidences in which county funding was secured for agency operations during the 1990s.

\begin{tabular}{|c|c|c|c|}
\hline Fiscal Year & Total Revenue & County & $\%$ County \\
\hline 1989-1990 & 273,420 & 173,325 & 63 \\
\hline 1990-1991 & 259,930 & 180,640 & 69.5 \\
\hline 1991-1992 & 257,197 & 159,315 & 62 \\
\hline 1992-1993 & 330,615 & 243,013 & 74 \\
\hline 1993-1994 & 237,137 & 141,509 & 60 \\
\hline 1994-1995 & 158,816 & 399,580 & 25 \\
\hline 1995-1996 & 150,111 & - & - \\
\hline 1996-1997 & 156,686 & - & - \\
\hline 1997-1998 & 205,944 & $* 50,000$ & 24 \\
\hline \multicolumn{4}{|c|}{$\begin{array}{l}\text { Source: Independent Auditors' Reports for Fiscal Years 1990, 1991, 1992, 1993, 1994, 1995, 1996, } 1997, \\
\text { and } 1998 .\end{array}$} \\
\hline \multicolumn{4}{|c|}{$\begin{array}{l}\text { *This revenue was actually federal revenue sharing dollars, initially earmarked for an independent liv- } \\
\text { ing center. However, the Bureau had to submit a funding proposal to the Commissi oners in } 1998 \text { in } \\
\text { order to secure and utilize thesefunds. }\end{array}$} \\
\hline
\end{tabular}

\section{Saving the Safe Place/Host Homes Program}

By the start of 1992, the Bureau's Safe Place/ Host Homes program, a crisis intervention program that served primarily teenage runaways and other youth at risk for reoccurring abuse or neglect, was experiencing substantial funding difficulties. The program needed to generate $\$ 18,000$ in revenue in order to meet its annual budget. The bureau's executive director delegated the responsibility of securing revenueto alleviate this deficit to theSafe Place/ Host Homes coordinator. The program coordinator quickly found that officials from local city governments viewed the funding of social services to be the responsibility of county government. When the coordinator began to approach elected county officials on an individual basis to elicit funding support, she found an ally in one of three members of the Johnson County Board of Commissioners. This Commissioner encouraged the coordinator to submit a written proposal to the Board of Commissioners for a formal hearing. After the $\$ 18,000$ funding request was approved by the Commissioners in order to alleviate the Safe Place/ Host Homes' program deficit, one of the commissioners volunteered to present the proposal to the Johnson County Council for final approval. This action ultimately resulted in the bureau securing $\$ 18,000$ from county officials. 


\section{Rescuing the Bureau-Twice}

As with most nonprofit human service agencies, the Bureau continued to exhibit a reliance on local governmental funding throughout the 1990s. In 1998, when it became obvious to the Bureau's professional staff and board members that county financial assistance was again needed due to a shortfall in the agency's operating budget, the Bureau's executive director contacted a county commissioner for advice. This former family physician and ally of the Bureau encouraged the director to submit a funding proposal to the Commissioners. Despite a heated debate between the agency's representatives and one of the commissioners during the hearing, the $\$ 20,000$ funding request was approved by a two-to-one vote. Since this funding request was acquired from the County Commissioner's discretionary account, approval from the County Council was not necessary.

Some of the Bureau's success in attaining county funding in November 1998 could be attributed to timing. The Bureau was fortunate to have the current county treasurer on its board; she encouraged agency staff to pursue funding toward the end of the calendar year since this is a time when discretionary funding from the County Commissioners was historically more obtainable. Although the agency's long time ally had retired from the Board of Commissioners before Bureau officials were able to submit an additional funding request, the timing of this proposal may have paid off again, as the $\$ 12,000$ request received unanimous approval from the Commissioners. A key difference between this funding hearing and the argumentative nature of the previous year's hearing was the absence of a debate on the details of the funding proposal. The Commissioner who had voted against the Bureau's request the previous year believed that state government, rather than county government, needed to be funding local nonprofits. This Commissioner also voiced concern about new funding requests potentially impeding the county's ability to cover construction costs related to the local jail. Some of the combativeness of 1998's hearing may have been avoided by steps bureau staff and board members enacted prior to the hearing. These steps included individual meetings held with each of the Commissioners prior to the hearing with the agency director and having an experienced and highly respected local judge speak on behalf of the Bureau at a monthly Board of Commissioners budget proposal hearing.

\section{Discussion of Funding Success}

The JCYSB's experience with securing funding is consistent with other studies that demonstrate nonprofit dependence on governmental revenue for survival (i.e., Galaskiewicz \& Bielefeld, 1998; Gronberg, 1993; Salamon, 1987). In building upon this previous research, this study shows the vital role local governments play in sustaining community-based nonprofits. In order to attain funding from local officials, agency leaders must devise strategies that consist of mobilizing other local organizations in their defense, actively promoting their services, and negotiating satisfactory solutions to their fiscal needs. The dynamic process of negotiating and bargaining with public officials and identifying influential allies who will "make the case" for an agency's funding requests, requires that nonprofit leaders possess considerable political skills. These generic political skills may be more important in acquiring resources and subsequent survival than the technical or managerial skills required for day-to-day operational activities. 


\section{Judges as Service Consumers}

As demonstrated by this case study, local public officials, specifically judges, play a key role in acquiring resources for court-related nonprofits. Constitutional scholar William Morrow (2000) views judges as the only public officials who consistently advocate on behalf of marginalized groups, such as homeless youth and children who are victimized by abuse. The history of judges advocating on behalf of disenfranchised groups can be traced to influential court decisions such as the Brown vs. Board of Education in 1954 (Morrow, 2000). Since judges often hold lifetime positions and many are appointed rather than elected, they do not have the same need to please constituency groups as state or national representatives and may therefore be more inclined to create laws that promote social justice.

In light of relatively long career tenures and considerable control over local resources (everything from courts to jails), judges often possess considerable influenceover county and city budgets; this political clout can beemployed to enhancethe likelihood of a nonprofit being funded by local taxpayers. Since nonprofits continue to play an integral part in the comprehensive strategies implemented by family courts nationwide, it is definitely in the interest of judges to enhance their survival.

In light of the "make or break" role judges often play in resource acquisition, nonprofit administrators need to view these local officials as prime consumers of their services. As program consumers, judges need to be provided with regular statistics on program participants and be involved in significant programmatic changes. They also need to be considered primary advisors when services are being created and as key sources of praise and criticism when program evaluations are being administered. Thus, when agency directors view judges as consumers, it only seems logical to have them periodically evaluate programs through written reports. Ultimately, the more judges are included in the service delivery strategies of nonprofits, the more they will perceive themselves as consumers and, more importantly, be personally invested in the sustainability and survival of the agency(ies). As highly invested and active recipients of court-related services, judges will be more likely to advocate on behalf of nonprofits when new resources need to be acquired.

\section{CONCLUSION}

This article highlights the symbiotic relationship between human service agencies and local governmental institutions. In light of these findings, local judges who depend upon a wide variety of social services in order to operate family court systems should be viewed as natural allies in combating governmental cuts or, at least, in keeping these cuts to a minimum. Furthermore, judges should be viewed as service consumers and need to be kept appraised of program outcomes. Ultimately, judges possess the power and influence to potentially make or break an agency and are more likely to invest time in social service agencies than other officials such as state or local representatives. In these times of federal and state budget deficits and subsequent budgetary shortfalls experienced by many social service providers, agency leaders need to align with local judges "now more than ever," as the John Cougar Mellencamp lyric goes. 
Once judges are on board with an agency's funding strategy, these local officials can be very effective in making the case for perpetuating or increasing agency funding. Program data that judges can employ to advocate for continued funding of court-related services include the following:

- Quantitative data that highlights the costs of providing community-based social services vs. the costs of detention, incarceration, or hospitalization. For example, the Johnson County Bureau compared the cost of providing a 24/7-crisis intervention program per runaway with the costs of incarcerating or hospitalizing a young person.

- Qualitative information in the form of anecdotes or case studies that reveal the "human side" of a child's experience with a community-based program. These narratives, coupled with statistical data, can convince county commissioners that social services need to be at least partially supported by taxpayer dollars.

A primary lesson to be learned from the Johnson County example is that qualitative information needs to be presented initially to funders as a vehicle for captivating their attention. Once their attention is gained, quantitative data, especially when presented in terms of cost savings to taxpayers, makes for a highly effective funding strategy.

Thesefindings also suggest that social work courses need to prepare students for the highly competitive and diverse nature of social service delivery. Social work is not just about the provision of services to individuals, families, and small groups. Social work incorporates advocacy, community organizing, and organizational and social policy development (Brueggemann, 2002). In light of the most severe funding cuts many state and local governments have experienced in the last 50 years, non profit agencies must compete with for-profit hospitals and outpatients clinics and with local police departments and other governmentally funded services impacted by revenue cuts. Schools of social work need to implement innovative strategies for training emerging social work professionals to work effectively within the nonprofit world in the current political and economic climate. For example, through a series of required research classes, the Kent School of Social Work at the University of Louisville teaches master's level students to work with local nonprofits to evaluate and document programmatic outcomes and effectiveness. Each student is required to complete a research project in conjunction with a local agency over the course of two semesters during his or her second program year. These projects, which often take the form of program evaluations, assist cash strapped agencies in preparing outcome data for grants and other funding pursuits.

In summary, partnerships made between agency leaders and governmental officials, especially local judges, constitute a starting point for an organization's overall survival and growth strategy. Community-based agencies often play the silent partners in the symbiotic relationship between human service agencies and local governmental officials. While the high profile, typically sensationalized murder and other felony cases judges preside over are often featured as front page news, the efforts of agency staff who work in tandem with judges to ensure that the needs 
of vulnerable children and families are cared for often go unnoticed. Indeed, the only time human service workers and their clients are typically featured in papers is when the social service delivery system fails to serve the public well, such as in cases of fraudulent or abusive behavior perpetrated by social service workers. Local judges who often bask in the rays of the media can shed somenecessary light on the central role played by agencies in providing a host of court-related services for disenfranchised youth.

\section{References}

Besel, K. (2000). Factors that impact the survival of nonprofit organizations: The case of the Indiana youth service bureaus. Unpublished doctoral dissertation. University of Louisville, Louisville.

Besel, K. (2001). The role of local governmental funding in nonprofit survival. Advancesin Social Work, 2(1) 39-51.

Blaisure, K., \& Geasler, M. (1996). Results of a survey of court-connected parent education programs in U.S. counties. Family and Conciliation Courts Review, 34(1) 23-40.

Bocage, M.D., Homonoff, E.E., \& Riley, P.M. (1995). Measuring the impact of the fiscal crisis on human service agencies and social work training. Social Work, 40, 701-707.

Brueggemann, W.G. (2002). The practice of macro social work. Belmont, CA: Wadsworth Group.

Clement, D. (1998). A compelling need for mandated use of supervised visitation programs. Family and Conciliation Courts Review, 36(2) 294-316.

Division of Historic Preservation and Archaeology. Johnson County Interim Report. (1985). Indianapolis, IN: Indiana Department of Natural Resources.

Family Services Report. (May 26, 1999). Silver Springs, MD: CD Publications.

Ferris, J.M., \& Graddy, E. (1989). Fading distinctions among the nonprofit, government, and for-profit sectors. In V.A. Hodgkinson, \& R.W. Lyman (Eds.), Thefutureof thenonprofit sector: Challenges, changes, and policy considerations. San Francisco: Jossey-Bass.

Galaskiewicz, J., \& Bielefeld, W. (1998). Nonprofit organizations in an age of uncertainty. New York: Aldine De Gruyter.

Greer, A.L., \& Greer, S. (1983). Cities and sickness: Health care in urban America. Beverly Hills, CA: Sage.

Gronberg, K. (1993). Understanding non-profit funding. San Francisco: Jossey Bass.

Hodgkinson, V.A., Weitzman, M.S., Toppe, C., \& Noga, S. (1992). Nonprofit Almanac 1992-1993: Dimensions of theindependent sector. San Francisco: Jossey-Bass Publishers.

Hodgkinson, V.A., Weitzman, M.S., Abrahams, J.A., Crutchfield, E.A., \& Stevenson, D.R. (1996). Nonprofit Almanac 1996-1997: Dimensions of theindependent sector. San Francisco: Jossey-Bass.

The Indiana Donor's Alliance, Annual Report, 1998. 22 East Washington Street, Indianapolis, IN, 46204.

The Indiana Youth Services Association Red Book, 1998. 309 West Washington Street, Suite 245, Indianapolis, IN, 46204.

The Indiana Youth Service Association Red Book, 2002. 309 West Washington Street, Suite 245, Indianapolis, IN 46204.

Jarman-Rohde, L., McFall, J., Kolar, P., \& Strom, G. (1997). The changing context of social work practice: Implications and recommendations for social work educators. Journal of Social Work Education, 33, 2946.

The Johnson County Youth Service Bureau Meeting of the Board of Directors Minutes. 1997-1998. P.O. Box 115, Franklin, IN 46131.

The Johnson County Youth Service Bureau History. 1996. P.O. Box 115, Franklin, IN 46131. 
Kaye, J., \& Lippman, J. (1998). New York state unified court system: Family justice program. Family and Conciliation Courts Review, 36(2) 144-178.

Morrow, W.L. (2000). A republic if you can keep it: Constitutional politics and public policy. New Jersey: Prentice Hall.

Ortiz, E.T., \& Bassof, B.Z. (1988). Proprietary hospital social work. Health and Social Work, 13, 114-121.

Peters, T.J., \& Waterman, R.H. (1982). In search of excellence: Lessons from America's best run companies. New York: Harper and Row.

Peterson, J.E., \& Strachota, D. (1991). Local government finance: Concepts and practices. Chicago: Government Finance Officers Association.

Salamon, L.M. (1987). Partners in public service: The scope and theory of government-nonprofit relations in the modern welfare state. Journal of Voluntary Action Research, 16(1-2), 29-49.

Shafritz, J.M., \& Russell, E.W. (2003). Introducing public administration ( $3^{\text {d }}$ Ed.) New York: Longman.

Sheppard, J.P. (1995). A resource dependence approach to organizational failure. Social Science Research, 24(1), 28-62.

Strom-Gottfried, K. (1997). The implications of managed care for social work education. Journal of Social Work Education, 33, 7-18.

\section{Author's Note:}

Address correspondence to: Karl Besel Ph.D., Kent School of Social Work, University of Louisville, Louisville, Kentucky 40292, USA. E-mail: kbesel@iuk.edu 